to develop, against a mere $£ 15$ million for the Trident $3 \mathrm{~b}$, the alternative aircraft. In the circumstances, it was obvious what the outcome would be.

Despite the cancellation, $\mathrm{BAC}$ seems to have plenty of work; for one thing, it will be responsible for the British end of the Concorde production. The BAC 1-11, the company hopes, will continue to sell for a good time yet, and there may still be a few orders for the VC 10 and the Lightning. And the news that the Trident $3 \mathrm{~b}$ is to be developed is bound to be an encouragement to Hawker Siddeley, disappointed by the Government's refusal to sell Buccaneers and Nimrods to South Africa. BEA is expected to want about 40 Tridents, and there may be a few orders from elsewhere now the decision to go ahead has been taken. But BEA will only accept the aeroplane on sufferance, and presumably as collateral to a Government agreement to provide the corporation with a financial reconstruction along the same lines as that enjoyed by BOAC. This is because BEA believes that the Trident will be more expensive to fly than the alternatives, one of which is the Boeing 727-200.

The alarming feature of the situation is not that the Government now pays the piper--that is probably inescapable-but that it is calling such a peculiar medley of tunes. While the Board of Trade has been mulling over the 2-11, the Ministry of Technology has been lavishing its formidable enthusiasm on the European airbus, a collaborative project in which France, West Germany and Britain are involved. To judge by the published reactions of some of the airlines, the airbus is no more immediately attractive than the 2-11. What the Government should now be asking itself is whether the $2-11$ would have been more attractive clad in the guise of European collaboration. Looking at it another way, would the airbus have seemed so desirable if BAC had proposed to build it alone? And why should two projects which clearly influence each other be the responsibilities of separate ministries? There is a real danger that the worthwhile aim of European collaboration is being used to justify projects which cannot justify themselves. That kind of muddled thinking will serve nobody's purposes but those of the United States aircraft companies.

\section{Fall-out over Britain}

Three Chinese nuclear explosions have occurred since the last recorded measurements were made in the United Kingdom of fission products in rainwater and airborne dust. In addition, France tested several nuclear devices in the South Pacific between June 1966 and July 1967. But in spite of this the latest Atomic Energy Authority research group report, Radioactive Fallout in Air and Rain: Results to the Middle of 1967 (UKAEA, 7s.), shows that the concentration of long-lived fission products over the United Kingdom has continued to decrease.

Prepared by the Health Physics and Medical Division of the Atomic Energy Research Establishment in Harwell, Berkshire, the report describes methods of sampling and analysis which were used over the period January 1966-July 1967: the data have been tabulated and, where appropriate, have been presented in graphical form. Airborne dust was sampled at one metre above ground by passing appropriate quantities of air through cylindrical filters of esparto grass paper at a number of stations in Britain, Gibraltar, Hong Kong, and Pretoria and Aspendale in Australia. Samples of rainwater were collected in polythene bottles, containing carrier solution to reduce loss by adsorption, at eight stations in Britain and twenty stations elsewhere. Individual activities were determined either by radiochemical methods or by gamma-ray spectrometry.

The mean deposition of $\mathrm{Sr}-90$ in rainwater at Milford Haven for the first half of 1967 was found to be 50 per cent of that for the first half of 1966 . About onetenth of the long-lived fall-out in early 1967 was attributed to the Chinese explosion of December 28, 1966: this increase was sustained for several months because debris had been injected into the stratosphere. No short-lived fission products, such as iodine-131 from the Chinese explosion of June 17, 1967, were detected in Britain although there is evidence of debris from this explosion in the autumn of 1967. It is interesting to note that plutonium-238 was released over the southern Indian Ocean in April 1964 when an American satellite containing a SNAP-9A power source of $17 \mathrm{KCi}$ of $\mathrm{Pu}-238$ failed to orbit. During the last few months of 1966, cumulative deposition of long-lived fission products was reduced for the first time as radioactive decay exceeded new deposition. In early 1967, however, deposition again slightly exceeded radioactive decay.

\section{Partially-hearing Children}

A suRver of the special arrangements made to help partially-hearing children has been published this week by the Department of Education and Science. In 1966 there were 162 units for such children in Ensland and Wales, of which the survey, conducted by HM inspectors of schools and medical officers, has covered 74.

The units are attached to schools and their purpose is to enable partially-hearing children to join the ordinary classes as soon as they are capable of doing so. Great care must be exercised in selecting children for the units, because severely deaf or otherwise retarded children will hold back the progress of the others. The survey recommended that more careful attention should be paid to the criteria for selecting children for the units. Children should be seen to have the prospect of learning to speak in a natural way more by listening than by lip-reading, and the unit's teacher should be consulted before selection so as to ensure that the child does not present too heavy a load of additional handicaps.

The survey suggested that units functioned better when they were large enough to include more than one class and more than one teacher. Though most of the units inspected are well supplied with audio-visual equipment and other aids, it is surprising that there has so far been little serious development in the use of programmed instruction or film loops.

All teachers of partially-hearing children are suitably qualified as teachers of the deaf. The survey found little to criticize in the standard of instruction within the units and indeed commended the progress made, but it pointed out that teachers who devote all their time to the units are often unaware of, and tend to underestimate, the standards reached by normal children.

The encouraging tone of the survey is marred only by the widespread lack of understanding found to exist in 
parents' attitudes towards their children's social and educational handicap. The survey stresses that parents need guidance and support in helping them to accept that their child may not make normal progress without special assistance.

\section{Water Development}

Is its annual report, whose principal conclusion is that Britain has too much water-not too little the Water Resources Board gives details of some intcresting research being carried out under its aegis. There has, for example, becn a programme of research into the regulation of the river Dee. Work on the generation of synthetic river flow data has been in progress at the Water Research Association and Lancaster University, and mathematical models representing catchment response are being studied at Imperial College. At the same time, attention is being paid to the problems of fisheries in the river, and it is hoped to build a fish counting station with an experimental electric fish barrier.

Less progress has been made in investigations of artificial recharge as a means of augmenting resources, largely owing to lack of staff. The report suggests that, although desalination plants similar to those built and projected in the United States will not bc profitable in Britain in the immediate future, there is sense in the use of flash distillation plants in conjunction with conventional surface reservoirs to meet intermit. tent excess demands. It is important, therefore, that operating experience of a multi-stage flash distillation plant should be obtained in Britain. The pilot electrodialysis plant in Essex for desalting brackish ground water from the chalk is now in operation, however, and there is a possibility that such a system could be used for reclamation of water from industrial and sewage effluents.

A most important part of the Water Resources Board's programme is the development of automatic hydrometric instrumentation. It is hoped that by mid-1968 equipment will be available for recording climatological and river water quality data on magnetic tape in such a way that the information can easily be fed into a computer. The board has negotiated with instrument manufacturers as a group, rather than individually, and feels sure that the advantages of this particular procedure have been significant. An ICT $190 \mathrm{l}(\mathrm{S})$ computer has very recently been acquired, and a team of staff to handle it recruited. The new com. puter section will serve all the divisions of the board. At present river flow data have been processed for river authorities, and the new computer will allow the service to be extended to cover climatic and other data.

The total expenditure of the board on research and on contributions for the support of university and river authority work was $£ 212,500$ last year.

\section{Production in Japan}

JAPAN is expected to overtake West Germany in the production of motor vehicles this year, and so become the second largest motor manufacturer in the world. More than three million cars will have been built, an increase of no less than 40 per cent since 1966 . Nor will this rate of growth fall, for production in 1968 should easily exceed four million vehicles.

Japanese exports used to be thought of as imitative and voluminous. Japan's achievements in shipbuilding and light engineering have convinced. Westerners that the first of these epithets is unjustified, but it would surprise many to know that Japan's exports in 1966 were little more than half those of Britain- $\$ 8,450 \mathrm{~m}$ against $\$ 14,000 \mathrm{~m}$, at the old rate of exchange. But if those in the West have exaggerated Japan's export performance, they have paid little attention to her importance as a producer of goods, as the table shows.

W. Ger-

Japan many Britain Erance Italy

Sulphuric acid

Synthetic

fibres

Steel

Motor

vehicles

Electricity

TV sets

Ships

\begin{tabular}{|c|c|c|c|c|}
\hline $5 \cdot 66$ & $3 \cdot 06$ & $3 \cdot 3$ & $2 \cdot 9$ & 4.75 million tons \\
\hline $\begin{array}{r}1,098 \\
41\end{array}$ & $\begin{array}{r}I, 025 \\
36\end{array}$ & $\begin{array}{r}846 \\
27\end{array}$ & $\begin{array}{r}475 \\
19\end{array}$ & $\begin{array}{l}650 \text { million } 1 b . \\
12.6 \text { million tons }\end{array}$ \\
\hline $\begin{array}{r}1 \cdot 88 \\
180\end{array}$ & $\begin{array}{l}2 \cdot 9 \\
172\end{array}$ & $\begin{array}{l}2 \cdot 2 \\
148\end{array}$ & $\begin{array}{l}1 \cdot 5 \\
101\end{array}$ & $\begin{array}{l}11.4 \text { million } \\
82 \text { thousand million } \\
\text { units }\end{array}$ \\
\hline $\begin{array}{l}4 \cdot 2 \\
5 \cdot 4\end{array}$ & $\begin{array}{l}2 \cdot 8 \\
1 \cdot 02\end{array}$ & $\begin{array}{l}1 \cdot 6 \\
1.07\end{array}$ & $\begin{array}{l}1 \cdot 25 \\
0.48\end{array}$ & $\begin{array}{l}1.2 \text { million } \\
0.44 \text { million tons } \\
\text { launched }\end{array}$ \\
\hline
\end{tabular}

Statistics of Industrial Production, 1965.

The foregoing table demonstrates the somewhat surprising fact that even in 1965, Japan was producing more steel, electricity, television sets, and, of course, ships than France and Italy combined, and that her output of synthetic fibres and motor vehicles was even then comparable with the combined totals of those two countries. It is interesting to reflect on the difference between the economic and political weights of the first four countries listed here. Japan's reliance on the United States as a trading partner precludes extravagant political gestures. Perhaps the next few years will see Japan rise to a diplomatic importance commensurate with her strength.

\section{Pooling Ocean Resources}

TwENTY-EIGHT nations have joined in a proposal to set up a United Nations committee to study the peaceful international exploitation of the ocean floors of the world: the United States is a sponsor of the proposal.

According to a draft resolution presented to the General Assembly's main political committee, the proposed committee will be required to conduct a survey of the past and present activities of the United Nations and its various agencies regarding the ocean floor and of existing international agreements concerning them; to summarize the scientific, economic, technical, legal and other problems which are involved in intcrnational use of underwater resources; and, finally, to suggest the practical means by which international co-operation could be promoted in the explora. tion, conservation and use of the ocean floor and its sub-soil.

The recommendation grew out of a debate on the subject in the political committee, and it was Malta which suggested that resources beneath the sea should be exploited for the benefit of all mankind. In deference to national claims of territorial watcrs, the draft resolution restricts its recommendations to the "sea bed and the ocean floor, and the sub-soil thereof, underlying the high seas beyond the limits of present national jurisdiction". Before the new committee can be set up, however, the draft resolution must 